\title{
Investigation of Biochemical Effect of Phenols Extract Isolated from Coriandrum sativum Seeds Against Echinococcus granulosus Parasite in Vitro
}

\author{
Abbas Dawwas Matter Al-Maliki \\ Chemistry Department - College of Education - University of Basrah \\ Basrah - Iraq
}

\begin{abstract}
:
This study was carried out to investigate effect of phenols extract isolated from Coriandrum sativum seeds extract against Echinococcus granulosus parasite gotten from livers of sheep infected by hydatid disease in Basrah abattoir . It was found that increase of concentration of extract led to decrease of protoscolices viability and the number of dead protoscolices increased with increase of days . Also the concentration of $(0.75 \mathrm{gm} / \mathrm{ml})$ had the higher effect on viability of protoscolices where it was noticed that this concentration killed all protoscolices after three days of treatment wheras the concentration of $(0.25 \mathrm{gm} / \mathrm{ml})$ was the less effect where it led to kill protoscolices after seven days of treatment with extract . The viability percentage reached to zero at concentration of $(0.75$ $\mathrm{gm} / \mathrm{ml})$ in the third day but at concentrations $(0.5$ and $0.6 \mathrm{gm} / \mathrm{ml})$ was zero in the fourth day . Also it was found that protoscolices viability percentage was zero in the seventh day of treatment by using concentration of $(0.25 \mathrm{gm} / \mathrm{ml})$. Therefore phenols extract concentration of $(0.75 \mathrm{gm} / \mathrm{ml})$ can be used as a medicinal herbal substitute instead of antibiotics but it needs further clinical studies .
\end{abstract}

Key words :

Phenols extract, Coriandrum sativum, Echinococcus granulosus, hydatid disease, protoscolices viability percentage. 
Introduction:

Echinococcal disease ( ED ) is a zoonotic infection caused by cestodes of the genus Echinococcus . Alveolar echinococcosis results from infection with the species Echinococcus multilocularis . This disease or it is named hydatid disease is caused by larvae of the tapeworm echinococcus. Four species are recognized and the vast majority of infestations in humans and animals are caused by Echinococcus granulosus . ( 1,2) . This parasite causes cystic echinococcosis , which has a worldwide distribution . The clinical presentation of hydatid disease is often non-specific and many patients may be asymptomatic . The symptom depends on the size and site of the lesion and the accessibility of the organ involved for clinical examination - Infections by hydatid disease in human and animals most commonly occur in the liver followed by the lung ,the two organs can be affected in humans simultaneously in about 5 $13 \%$ of cases ( 3,4) . Echinococcus granulosus, the causative agent of hydatid disease, is a cosmopolitan parasite of man and animals . The parasite has at least nine hosts adapted strains , most of which are occurring throughout the world .

Sheeps and dogs are the usual definitive host, while a wide range of mammals including man can be intermediate host .

The eggs of this parasite represent the characteristic feature of Taeniid eggs and are ellipsoid to spherical in shape. Hatching comprises of disintegration of the egg envelopes, membranes and release of oncosphere which may require the action of proteolytic enzymes in the stomach and / or intestine $(5,6)$.The ED disease occurs when humans ingest the hexacanth egg of the dog tapeworm . Hydatid disease is prevalent especially in sheep rearing areas . Rupure or episodic leakage from a hydatid cyst may produce fever , pruritis , urticaria and eosinophilia ( 7 ).

Many studies were carried out for treating echinococcal disease by using different drugs such as albendazole , mebendazole and praziquantel where it was found that these drugs decrease the number and size of hydatid cysts ( 8,9 ).

Also many studies were achieved for treating echinococcal disease by medicinal plants such as Nigella sativa , the aqueous and alcoholic extracts of this plant showed a high decreasing in viability of protoscolices of Echinococcus granulosus. Also it was noticed that all protoscolices were killed by using concentration of ( $15 \%$ and $20 \% \mathrm{gm} / \mathrm{ml}$ ) of alcoholic and aqueous extracts respectively ( 10 ).

A significant decreasing for Echinococcus granulosus protoscolices viability, was recorded by using alcoholic extract of Pimpinella anisum and Plantajo major ( 11 ).

$$
\text { Coriandrum sativum }
$$

Ombelliferae ) is one of medicinal plants used for treating many diseases . It is an annual herbaceous plant , 20 $-50 \mathrm{~cm}$ high and with white or pink flowers, its fruits can be used as a spice ( 12 ) . Recently Coriandrum sativum extracts have provoked interest as sources of natural products and it has been screened for its potential uses as alternative remedies for infectious diseases, ensuring protection from the toxic effect of oxidant. Also, it has many active chemical compounds such as essential 
oils, phenols, terpenes and linalool alcohol . Essential oils of Coriandrum sativum are used as antibacterial agents $(13,14)$ therefore in this study phenols extract isolated from seeds of Coriandrum sativum was used as anti-parasite agent to investigate viability of Echinococcus granulosus protoscolices .

\section{MATERIALS \& METHODS}

\section{Plant Collection}

Coriandrum sativum seeds were bought from local market of $\mathrm{Abu} \mathrm{Al}-$ Khaseeb region in Basrah, the plant is classified in the herbarium of science college in university of Basrah . Seeds were washed by distilled water and dried then ground and collected in glass containers at room temperature until use .

Preparation of Solutions

Phosphate buffer saline solution ( PBS ) was prepared by using sodium chloride ( $8.0 \mathrm{gm}$ ), hydrous disodium phosphate ( $2.89 \mathrm{gm}$ ), dihydrogen potassium phosphate ( $0.2 \mathrm{gm})$ and potassium chloride ( $0.2 \mathrm{gm}$ ) . All chemicals were dissolved in a certain volume of distilled water then the volume was made up to 1.0 liter . The solution was sterilized in autoclave at $121^{\circ} \mathrm{C}$ and pressure of $15 \mathrm{p} / \mathrm{inch}^{2}$ for half hour (15) .

Kreps-Ringer Solution (K.R.S) was prepared by using sodium chloride (0.48 gm), potassium chloride $(0.157 \mathrm{gm})$, calcium chloride $(0.0137$ gm), sodium bicarbonate (0.281 gm), dihydrogen sodium phosphate $(0.097$ gm), hydrogen sodium phosphate $(0.490 \mathrm{gm})$, magnesium sulphate $(0.072 \mathrm{gm})$, streptomycin $(0.2 \mathrm{gm})$ and penicillin $(0.4 \mathrm{gm})$. All chemicals were dissolved in 1 liter of distilled water and $\mathrm{pH}$ was adjusted to 7.4 , then the solution was sterilized in autoclave at $121^{\circ} \mathrm{C}$ and pressure of $15{\mathrm{p} / \mathrm{inch}^{2}}^{2}$ for half hour. After that , $(0.09 \mathrm{gm})$ of glucose was added and the solution was left to decrease its temperature (16) .

Antibiotics (penicillin and streptomycin) solutions were prepared by dissolving ( $0.1 \mathrm{gm})$ of each one in $100 \mathrm{ml}$ of distilled water ( 17 ) .

Collection of Hydatid Cysts

Hydatid cycts were collected from livers of sheep infected by Echinococcus granulosus parasite in Basrah abattoir, then cysts were placed in cork containers and directly transferred to the laboratory then they were treated at the same day .

Collection of Protoscolices

Hydatid cysts surface was sterilized by a piece of cork wetted by ethanol ( $70 \% \mathrm{v} / \mathrm{v})$. The liquid of cysts was withdrawn by $10 \mathrm{ml}$ plastic syringe and transfered into a sterilized container then the cyst was opened and the residue liquid was withdrawn by a needless syringe and placed in the container, then the cyst liquid was put in sterilized test tubes and precipitated in centrifuge with $\mathbf{3 0 0 0}$ cycle / min for 10 minute .

After that protoscolices were separated from filterate and washed 5 times by phosphate buffer saline solution then protoscolices were isolated by a small drawing brush and they were collected in test tubes and precipitated by centrifuge, then antibiotics (penicillin and streptomycin) were added into PBS solution during the second washing. After that kreps-Ringer Solution + hydatid cyst liquid with ratio (1:4) 
were added into precipitate then protoscolices were treated with phenols extract (17) .

\section{Isolation of Phenols}

Fifty grams of seeds ground of Coriandrum sativum were added into $250 \mathrm{ml}$ of $(2 \% \mathrm{v} / \mathrm{v})$ hydrochloric acid and the mixture was put in water bath for 80 minute then it was filtered by Buchner funnel by using Whatman no.1 filter paper. The precipitate was canceled and the filterate volume was measured then diethyl ether was added into filterate with the same volume of filterate and the mixture was placed in waterbath for 50 minute , then it was evaporated by using rotary evaporator and the crude weight was $4.52 \mathrm{gm}(18$ ).

\section{Protoscolices Counting}

$\mathbf{0 . 1} \mathrm{ml}$ of colloidal solution containing proloscoieces was taken and put on glass slide then one drop of aqueous Eosin stain $(0.1 \%)$ was added on the slide. The alive protoscolices were stained with green colour whereas the deads were stained with red colour ( 19 ) .

Investigation of Effect of Phenols Extract on Protoscolices Viability

After process of protoscolices counting, $1 \mathrm{ml}$ of colloidal solution containing 2000 protoscolices was taken and put in a test tube containing phenols extract with concentration of $(0.25 \mathrm{gm} / \mathrm{ml})$ then the protoscolices viability percentage was calculated during $1,2,3,4,5,6$, and 7 days after treatment with extract . This investigation was carried out by using concentrations of $(0.5,0.6$ and 0.75 gm/ml ) .

\section{RESULTS \& DICUSSION}

In this study , ( Kreps - Ringer + hydatid cyst liquid ) solution was used with ratio ( 1:4) because it the best for keeping viability of protoscolices since this solution contains nutritious chemical compounds such as proteins, carbohydrates, fats, ammonia and creatine ( 20$)$.

Table (1) indicates the effect of phenols extract at concentration of

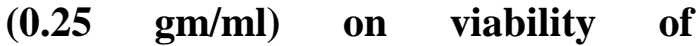
protoscolices, the results showed a significant decreasing in number of protoscolices from 18 at the first day to zero at the seventh day of treatment with extract. Many studies ensured that phenols are capable of killing protoscolices, then decrease of viability percentage (21) . Also it was noticed that the number of alive protoscolices decreased with increase of days .

Table ( 1 ) : Effect of phenols extract at concentration of $(0.25 \mathrm{gm} / \mathrm{ml})$ against Echinococcus granulosus protoscolices viability in vitro .

\begin{tabular}{|c|c|c|c|c|c|c|}
\hline \multirow{2}{*}{$\operatorname{tine}(4 x y)$} & \multicolumn{2}{|c|}{ 10. of protoscolires } & \multirow{2}{*}{$\begin{array}{l}\text { "ivbility } \\
\text { perteatoge }\end{array}$} & \multicolumn{2}{|c|}{ courrol prot甲 } & \multirow{2}{*}{$\begin{array}{l}\text { vibulibly } \\
\text { percentexy }\end{array}$} \\
\hline & total & alve & & total & alve & \\
\hline 1 & 20 & 13 & 90:4 & 15 & 15 & $100 \%$ \\
\hline 2 & 19 & 17 & $87.47 \%$ & 14 & 14 & $100 \%$ \\
\hline 3 & 18 & 15 & $33.3 \%$ & 100 & 59 & $99 \%$ \\
\hline 4 & 17 & 10 & $58.82 \%$ & 21 & 20 & $95.23 \%$ \\
\hline 5 & 10 & 2 & $20 \%$ & 21 & 18 & зรกษ \\
\hline 6 & 12 & 2 & $16.66 \%$ & 20 & 17 & $85 \%$ \\
\hline$T$ & 20 & 0 & $0 \%$ & 20 & 16 & $50 \%$ \\
\hline
\end{tabular}


* The protoscolices viability percentage was calculated according to the following equation :

protosolices wability $\%=\frac{\text { no. of alite frotoscolices }}{\text { no of total pectososlioes }} \times 100$

From table (2) it was noticed that the extract concentration of $(0.5 \mathrm{gm} / \mathrm{ml})$ had a high effect where it was found that the number of alive protoscolices decreased in the course of time especially at fourth, fifth, sixth and seventh days therefore protoscolices viability percentage come to $0 \%$. This means that this concentration was more effective than concentration of $(0.25 \mathrm{gm} / \mathrm{ml})$. A study were carried out on Echinococcus granulosus, ensured that the high concentration of extract was more active than low concentration (11).

Table (2) : Effect of phenols extract at concentration of $(0.5 \mathrm{gm} / \mathrm{ml})$ against Echinococcus granulosus protoscolices viability in vitro .

\begin{tabular}{|c|c|c|c|c|c|c|}
\hline \multirow{2}{*}{ time (day) } & \multicolumn{2}{|c|}{ m. of protescalizes } & \multirow{2}{*}{$\begin{array}{l}\text { vishility } \\
\text { perrentage }\end{array}$} & \multicolumn{2}{|c|}{ cantrol group } & \multirow{2}{*}{$\begin{array}{l}\text { vishility } \\
\text { perrentag }\end{array}$} \\
\hline & total & also & & twal & also & \\
\hline 1 & 25 & 20 & $\infty \%$ & 4 & 48 & $100 \%$ \\
\hline 2 & 22 & 10 & $45.45 \%$ & 22 & 22 & $100 \%$ \\
\hline 3 & 25 & 7 & $28 \%$ & 30 & 29 & $9666 \%$ \\
\hline 4 & 4 & 0 & $0 \%$ & $3 t$ & 23 & $3419 \%$ \\
\hline 5 & 2 & 0 & $0 \%$ & 30 & 30 & $100 \%$ \\
\hline 6 & 31 & 0 & $0 \%$ & 30 & 18 & $60 \%$ \\
\hline 7 & 18 & 0 & $0 \%$ & 30 & 17 & $36.66 \%$ \\
\hline
\end{tabular}

The results in table ( 3 ) showed that phenols extract at concentration ( $0.6 \mathrm{gm} / \mathrm{ml}$ ) led to decrease alive protoscolices from ten at the first day of treatment to zero at the fourth day, this means that the concentration gave a significant decreasing . Also the protoscolices viability percentage decreased obviously from $\mathbf{6 6 . 6 6 \%}$ at the first day to $0 \%$ at the fourth, fifth, sixth and seventh days of treatment with extract . Many studies indicated that phenols extract isolated from many medicinal herbal plants, decreases the viability of protoscolices of Echinococcus granulosus because of linking these chemical compounds with chain of reactions of proteins metabolism which are necessary for protoscolices viability or because of ability of phenolic compounds to distruct the cell membrane containing fats and proteins therefore this process leads to death of Echinococcus granulosus parasite (22) .

Table ( 3 ) : Effect of phenols extract at concentration of $(0.6 \mathrm{gm} / \mathrm{ml})$ against Echinococcus granulosus protoscolices viability in vitro .

\begin{tabular}{|c|c|c|c|c|c|c|}
\hline \multirow{2}{*}{ fire (day) } & \multicolumn{2}{|c|}{ m. of protiscralises } & \multirow{2}{*}{$\begin{array}{l}\text { vistality } \\
\text { percentiog }\end{array}$} & \multicolumn{2}{|c|}{ ceatsal group } & \multirow{2}{*}{$\begin{array}{l}\text { viatility } \\
\text { percentuge }\end{array}$} \\
\hline & tonal & albe & & wotal & albe & \\
\hline 1 & 15 & 10 & $6666 \%$ & 40 & 4] & $100 \%$ \\
\hline 2 & 11 & 6 & $5454 \%$ & 13 & 13 & $100 \%$ \\
\hline 3 & 10 & 2 & $20 \%$ & 90 & 65 & $222 \%$ \\
\hline 4 & $\omega$ & 0 & $0 \%$ & at & $n$ & $\pi 954 \%$ \\
\hline 3 & 41 & 0 & $0 \%$ & 35 & 75 & $282 \%$ \\
\hline 6 & 13 & 0 & $0 \%$ & 32 & $n$ & $836 \%$ \\
\hline 1 & 28 & 0 & $0 \%$ & 32 & $n$ & $8180 \%$ \\
\hline
\end{tabular}

In table (4) the concentration of ( $0.75 \mathrm{gm} / \mathrm{ml}$ ) of phenols extract 
showed a great antiparasite activity against protoscolices viability . Invistigation of biochemical effect of this concentration indicated decreasing number of protoscolices with high percentage where all these protoscolices were died at the third day of treatment and the viability percentage come to $0 \%$. Also it was found that number of protoscolices were 12 at the first day but they come to zero at the fourth, fifith, sixth and seventh days, therefore the concentration of ( $0.75 \mathrm{gm} / \mathrm{ml}$ ) was the best to kill all protoscolices .

Table ( 4 ) : Effect of phenols extract at concentration of $(0.75 \mathrm{gm} / \mathrm{ml})$ against Echinococcus granulosus protoscolices viability in vitro .

\begin{tabular}{|c|c|c|c|c|c|c|}
\hline \multirow{2}{*}{ tine (by) } & \multicolumn{2}{|c|}{ a. ofpromescelikes } & \multirow{2}{*}{$\begin{array}{l}\text { rialisity } \\
\text { pextratage }\end{array}$} & \multicolumn{2}{|c|}{ teateol gevup } & \multirow{2}{*}{$\begin{array}{l}\text { vishility } \\
\text { pertange }\end{array}$} \\
\hline & wat & aline & & bal & aline & \\
\hline 1 & 24 & 12 & $50 \%$ & 15 & 15 & $100 \%$ \\
\hline 2 & 20 & 2 & $10 \%$ & 22 & 2 & $100 \%$ \\
\hline 3 & ut & 0 & $0 \%$ & 30 & 29 & $96 \operatorname{sex}$ \\
\hline 4 & 22 & 0 & $0 x$ & 31 & 23 & $7419 \%$ \\
\hline$s$ & 29 & 0 & $0 x$ & 31 & 18 & $8806 \%$ \\
\hline 6 & is & 0 & $0 x$ & 80 & $x$ & $8536 \%$ \\
\hline$?$ & 19 & 0 & $0 x$ & 30 & 17 & $5666 \%$ \\
\hline
\end{tabular}

The mechanism is explaind that phenols leads to disorder in respiratory process in mitochondria then inhibition of carbohydrates, fats and proteins metabolism leading to death of Echinococcus granulosus protoscolices ( 21 ) . Some studies ensured that phenols extract inhibits respiratory chain enzymes containing thiol group ( $-\mathrm{SH})$ which is substituted by carbonyl group present in phenols after oxidation of hydroxyl group ( - OH ) by molecular oxygen and elimination of a hydrogen molecule ( 23,11) .

It is noticed that concentration of ( $0.75 \mathrm{gm} / \mathrm{ml}$ ) has a greater effect than $(0.25, \quad 0.5$ and $0.6 \quad \mathrm{gm} / \mathrm{ml})$ concentrations because of its the high antiparasite activity to kill all protoscolices in less time.

\section{CONCLUSIONS}

Phenols extract isolated from Coriandrum sativum showed a great anti-parasite activity to decrease protoscolices viability of Echinococcus granulosus . The concentration of ( $0.75 \mathrm{gm} / \mathrm{ml}$ ) was the best because of its high activity to kill all protoscolices in less time therefore phenols extract at this concentration can be used as a medicinal herbal drug for treatment and curing of hydatid disease instead of some antibiotics used such as tinidazole, invermection and mebendazole but it needs further clinical studies.

\section{REFERENCES}

1. Ali, S. ; Joan, L.R ; Lilly, J.M. ; Ravi, B. and Thomas, J.M. , (2005). Echinococcal disease in Alberta, Canada : more than a classified opacity . Bio.Med. central Infections Diseases ., 5:34 .

2. Arora, V. ; Snijjar, I. and Gill, K.S., (2006) . Primary Hydatid Cyst. of Muscle - A Rare site ., Ind .J. Radiol . Image ., 16:239 - 241

3. Clinton, A.W and Peter, F.W. , (2005) ., Harrison's Principles of Internal Medicine, $16^{\text {th }}$ ed. , McGraw - Hill, Inc. , 1:1272 - 1277 . 
4. Morar, R. and Feldman, C. , (2003) . Pulmonary Echinococcosis . Europe, Respir. J. , 21:1069 - 1077 .

5. Thompson, R.C.A. and Lymbery, A.J. , (1995) . Echinococcus and Hydatied diseases ., CAB. International, Wallingford, UK, P. 1 - 37 .

6. Torgerson, P.R., (2003) . The use of mathematical models to simulate control options for Echinococcosis . Acta Tropica ., 85: 211 - 221 .

7. Abu-Eshy, S.A.,(1998).Some rare presentations of hydatid cyst (Echinococcosis granulosus).,J.R.Coll.Surg. Edinb. ,UK, 43:347-352.

8. Taghavi, S.A.,(2003). Nonsurgical treatment of cystic Echinococcus., Sem.J. vol. 2, No. 2 .

9. Vutova, K. ; Mechkov, G. ; Vachkov, P. ; Petkor, R. ; Georgiev, P. ; Handjev, S.; Ivoanov, A. and Tadrov, I. ; (1999) . Effect of Mebendazole on human cystic echinococcosis : The role dosage and treatment duration ., Ann. , Trop. Med. Parasitol ., 4:357 - 365 .

10. Al-Khuzai, J. H. R., (2005) . Evaluation of effectiveness of some plant extracts, drugs and electric current on viability of protoscolices of Echinococcus granulosus in vitro and vivo in white mice., Ph.D. Thesis, Education college, Qadisiya Unv., Iraq .

11. Hailat, N.; Al-Kahil, S.; Al-Kohi , A.; Lafi, S.; Al-Anif; Al - Darragii, A. and Batainch, Z. (1998) . Effect of Nigella sativa extracts on antibody response of rats vaccinated with Brucella vaccine. ( Rev. 1 ), Pharmaceutical Biology. , 36 ( 3 ): $217-221$.

12. Erturk, O ; Ozbucak, T. B. and Bayrak, A. (2006) . Herba Polonica, 52 ( 1 ) : 58 66 .

13. Vander, B. D. A. and Vietinck, A. J. ; (1991) . Screening methods for antibacterical and antiviral agents from higher plants ., In : Dey, P. M., Harborne, J. B. ( eds. ), Methods in plant Biochemistry, Academic Press, London, UK .

14. Lembert, R. J. W ; Skandamis, P. N ; Coote, P. J. and Nychas, J. E., (2001) . A study of the minimum inhibitory concentration and mode of action of Oregano essential oil, thymol and carvacrol. , J. Appl. Microbiol ., 91:453-462.

15. Hokelet, M. , (2002) . Ivermectin used in percutaneous drug injection method for the treatment of liver hydatid disease in sheep ., Gastroenterology ., Vol. 122 ( no. 4 ): 1- 8

16. Reisin , L. L ; Rabito , C. A. ; Rotunno , C. A. and Cereijido, M. , (1997). The permeability of the membrane of experimental secondary cysts of $\mathbf{E}$. granulosus to mebendazole., Inter. J. parasitol .,7:189-194.

17. Smyth, T. D. , (1985) . In vitro culture of Echinococcus. SPP. In : proceeding of the $13^{\text {th }}$. congr. of hydatilogy . Madrid, Espan . , pp. 84- 89 .

18. Harborne, J. B., (1973) . " Phytochemical methods " . st $^{\text {st }}$ ed. , Richard Clay. Ltd , Bungay, UK .

19. Smyth, T. D., (1977) . Strain differences in E. granulosus with special to the status of equire hydatidosis in United Kingdom ., Roy. Soc. Trop. Med. Hyg. , $71: 93-100$.

20. Kassis, A. F. and Taunner, C.E. , (1976) . The role of complement in hydatid disease in vitro studies,, Int. $\mathbf{J}$. parasitol ., $6: 25-35$.

21. Delorenzi , J. C. ; Attias, M. ; Gattas, C.R. ; Androde, C. ; Pinto, A. C. ; Henriques, A. T. ; Bou - Habib, D. C. and Saraira, E. M., (2000) . Anti lesishmanial activity of an indole alkaloid from Peshiera australis ., Antimicrob. Agents . Chemother ., 45 ( 5 ) : 1349 - 1354 .

22. Anthony, H. R., (1976) - Chemical microbiology - An Introduction to microbial physiology . $3^{\text {rd }}$ ed. , Butter worth and Co.(Publishers), London, UK.

23. Houghton, P.J.; Zarks, R. ; De-les- Heras, B. and Hoult, T.R.,(1995). Fixed oil of Nigella sativa and dried thymoquinine inhibit aeicosanoid generation in Leykocyte and membrane lipid ., Peroxidation . Med. Plant .,61(1): 3 36. 


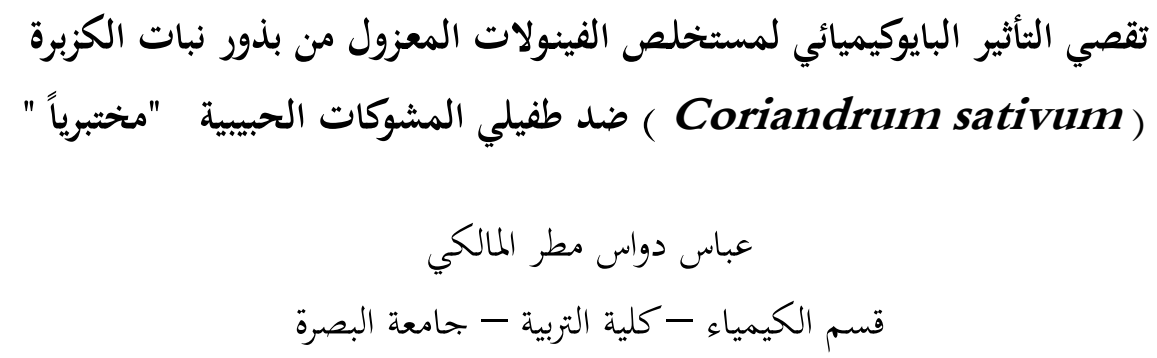

\section{الخلاصــة}

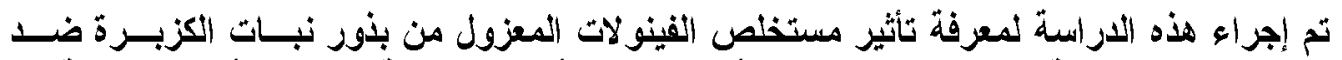

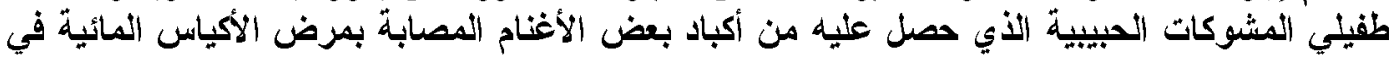
مجزرة البصرة .

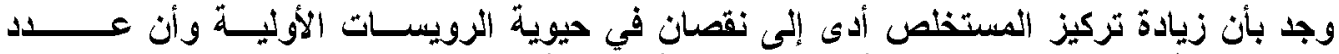

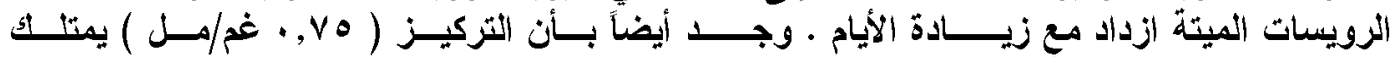

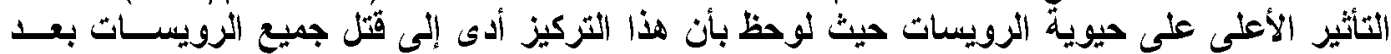

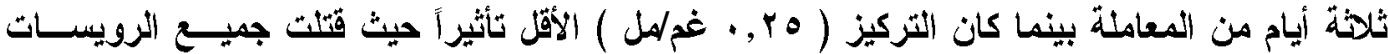

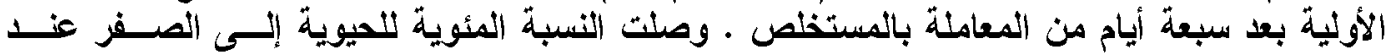

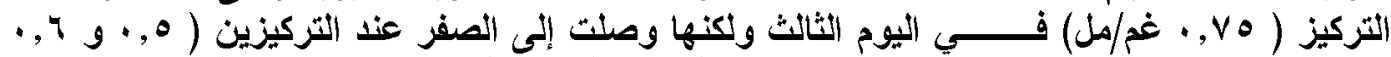

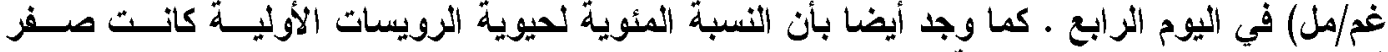

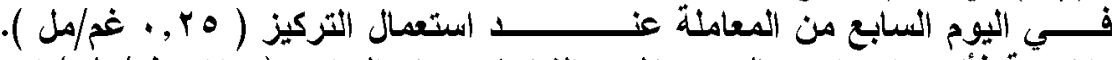

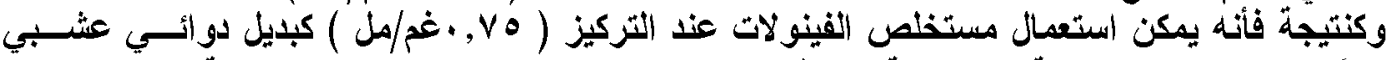

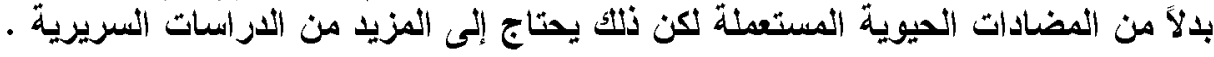

